\title{
ZABIEGI ZYGMUNTA III O POMOC ZAGRANICZNĄ NA WOJNĘ Z TURKAMI W 1590 ROKU*
}

\author{
DARIUSZ MILEWSKI
}

\begin{abstract}
Sigismund III's efforts to obtain foreign aid for the war against the Turks in 1590.
The paper presents Sigismund III's efforts to obtain foreign aid in the face of the war against the Turks expected in 1590. Polish efforts in Italy and Reich are discussed, but the main focus is on the imperial court and the Duchy of Prussia, from which the king expected the real help. I present the arguments of both sides and the reasons why Poland did not receive any aid from the emperor, but received it from Duchy of Prussia. I also point to the role of particular interests in bilateral relations between Poland and its political partners as well as the latter ones with the Ottoman Empire, which influenced the decisions on granting or refusing aid to Poland against the Turks.
\end{abstract}

STRESZCZENIE. Artykuł przedstawia zabiegi Zygmunta III zmierzające do uzyskania pomocy zagranicznej wobec spodziewanej w 1590 r. wojny z Turkami. Ukazano zabiegi polskie w Italii i Rzeszy, jednak wagę skupiono na dworze cesarskim i Prusach Książęcych, od których król spodziewał się realnej pomocy. Ukazano sposób argumentacji obu stron oraz przyczyny, dla których Polska nie uzyskała pomocy od cesarza, a otrzymała od Prus Książęcych. Wskazano przede wszystkim na rolę partykularnych interesów w relacjach obustronnych Polski i jej partnerów politycznych, a także tych ostatnich z Imperium Osmańskim, które zaważyły na podejmowaniu decyzji o udzieleniu bądź odmowie pomocy Polsce przeciw Turkom.

Author: Dariusz Milewski, Uniwersytet Kardynała Stefana Wyszyńskiego w Warszawie, Instytut Historii, ul. K. Wóycickiego 1/3, 01-938 Warszawa, Polska; d.milewski@uksw.edu.pl, ORCiD iD: 0000-0002-3255-7685

Keywords: Commonwealth, Ottomans, Habsburgs, Duchy of Prussia, army, finances

Słowa kluczowe: Rzeczpospolita, Osmanie, Habsburgowie, Prusy Książęce, wojsko, finanse

Balcanica Posnaniensia. Acta et studia, XXVIII/2, Poznań 2021, Wydawnictwo Wydziału Historii UAM, pp. 41 56, ISBN 978-83-66355-84-2, ISSN 0239-4278. Polish text with summaries in English and Polish

doi.org/10.14746/bp.2021.28.19

Wstąpienie na tron polsko-litewski Zygmunta III w 1587 r. i związany z tym upadek kandydatury habsburskiej arcyksięcia Maksymiliana były dobrze przyjęte przez Portę Otomańską. Skonfliktowanie Rzeczypospolitej z Cesarstwem było wszak na rękę suł-

* Artykuł powstał w ramach projektu badawczego Narodowego Programu Rozwoju Humanistyki, Akta skarbowe jako źródto do dziejów wojskowości staropolskiej za panowania Wazów (1587-1668), moduł 1.1, nr 11H 13033482. 
tanowi, zaangażowanemu aż do 1590 r. w wyczerpującą wojnę z safawidzką Persją. Niestety dobre początki polsko-osmańskich relacji zostały rychło zniweczone i już w 1590 r. oba państwa znalazły się na krawędzi wojny. Wśród przyczyn tego stanu rzeczy należy wyróżnić trzy elementy:

- porozumienie polsko-habsburskie, do jakiego doszło w wyniku zawarcia trakatów będzińsko-bytomskich w marcu 1589 r.,

- nowe akcje kozackie przeciw posiadłościom tatarskim i osmańskim nad Morzem Czarnym w tymże roku,

- zwłoka z wysłaniem wielkiego posła do Stambułu, który oznajmiłby wstąpienie na tron polsko-litewski nowego władcy.

Wszystkie te elementy miały swoje logiczne uzasadnienie. Porozumienie Zygmunta III z Rudolfem II było alternatywą dla wojny między obu monarchami, nie wróżącej zgoła korzyści żadnemu z nich wobec równowagi sił zbrojnych i przetrzymywania arcyksięcia Maksymiliana w niewoli polskiej. Przeciwnie, pacyfikacja między Krakowem a Pragą dawała Zygmuntowi III gwarancję bezpieczeństwa zachodniej granicy Polski i jego panowania, a zarazem otwierała możliwości działania na innych kierunkach. Królowi chodziło przede wszystkim o uniezależnienie się od potężnego kanclerza i hetmana wielkiego koronnego Jana Zamoyskiego oraz możliwość skierowania sił polsko-litewskich przeciw Moskwie, do czego nakłaniał syna król szwedzki Jan III Waza ${ }^{1}$.

Czynnik kozacki był trudny do opanowania, zwłaszcza wobec zaangażowania się sił zbrojnych Korony w odparcie najazdu habsburskiego jesienią 1587 r. i utrzymywanego aż do zawarcia traktatów będzińsko-bytomskich pogotowia wojennego na zachodniej granicy państwa. W tej sytuacji pozbawieni nadzoru Kozacy bez przeszkód wznowili łupieską działalność nad Morzem Czarnym, napadając w 1589 r. na Oczaków i krymski port Gözleve (Kozłów), a w kolejnej wyprawie atakując Akerman (Białogród) i Bendery (Tehinię) $)^{2}$. Uchwalona na wiosennym sejmie 1589 r. konstytucja, mająca utrzymać Kozaków w ryzach, pozostała więc martwą literą̧

Wreszcie opóźnienie w ekspedycji wielkiego poselstwa do Stambułu spowodowane było prozaiczną przyczyną, jaką były pustki w skarbie królewskim. Co prawda Zygmunt III już u progu rządów kontaktował się listownie z sułtanem Muradem III i w marcu 1588 r. przygotowano nawet instrukcję poselską dla sekretarza królewskie-

1 M. A. Pieńkowski, Trudna droga do władzy w Rzeczypospolitej. Sejm koronacyjny Zygmunta III 1587/1588 i sejm pacyfikacyjny 1589 roku, Warszawa 2021, s. 171-172.

2 M. Plewczyński, Wojny i wojskowość polska w XVI wieku, t. 3 (1576-1599), Zabrze-Tarnowskie Góry 2013, s. 107-110; T. Górski, Flotylle kozackie w stużbie Jagiellonów i Wazów, Gdańsk 2006, s. $132-133$.

3 Konstytucja ,,Zahamowanie ukrainnego swawoleństwa, [w:] Volumina Constitutionum, t. 2 (15501609), volumen 2 (1587-1609), red. S. Grodziski, Warszawa 2008, s. 115. 
go Jana Zamoyskiego herbu Grzymała, jednakże do wysłania wielkiego poselstwa nie doszło ${ }^{4}$.

Na skutki nie trzeba było długo czekać, gdyż w odpowiedzi na zbliżenie polskohabsburskie i wypady kozackie w sierpniu 1589 r. spadł na ziemie ruskie najazd tatarski, prowadzony osobiście przez chana Gazi II Gereja. Tatarzy zastali kraj praktycznie nieprzygotowany do obrony. Hetmani Jan Zamoyski i Stanisław Żółkiewski dysponowali ledwo 2 tys. żołnierzy kwarcianych. Sam król akurat w tym czasie wyruszał do Estonii na spotkanie z ojcem. Orda złupiła zatem bez większych przeszkód Ruś aż po Lwów i powróciła z jasyrem, zanim hetmanom koronnym udało się zebrać odpowiednią liczbę wojska dla przeciwstawienia się najeźdźcom. Był to pokaz sprawności militarnej polskich przeciwników i gorzki przedsmak tego, co mogło spotkać Rzeczpospolitą w razie większego zatargu z Osmanami ${ }^{5}$.

Spóźnione wielkie poselstwo polskie do Stambułu ruszyło wreszcie w sierpniu 1589 r., mijając się poniekąd z czambułami tatarskimi pustoszącymi Ruś. Na czele legacji stanął starosta drohobycki Paweł Uchański. Poseł nie miał szczęścia, gdyż w drodze złamał nogę, co jeszcze spowolniło i tak spóźnioną misję. Nad Bosfor dotarł wreszcie 26 lutego 1590 r., będąc już mocno schorowany. Osmanowie powitali go chłodno, czując urazę z powodu porozumienia polsko-habsburskiego i najazdów kozackich. Sprawę skomplikowała dodatkowo śmierć posła, która nastąpiła 6 marca 1590 r. Zastępujący go Stanisław Łaszcz bał się wykroczyć poza otrzymane instrukcje i dla uzyskania decyzji królewskiej wysłał do Warszawy podczaszego chełmskiego Mikołaja Czyżewskiego. Wiózł on listy od Turków, w których ci domagali się odbudowy zniszczonych zamków, ukarania sprawców ostatnich napadów, a nawet usunięcia Kozaków z Ukrainy, zwrotu dział, uwolnienia jeńców i rocznego haraczu w wysokości 100 funtów srebra (250-300 tys. talarów) — dając jako alternatywę przyjęcie islamu przez króla i jego poddanych ${ }^{6}$. Były to oczywiście warunki nie do przyjęcia, które kazały Polakom serio myśleć o grożącej wojnie z imperium osmańskim.

4 Zygmunt III do Murada III, Kraków, 30.01.1588, Archiwum Główne Akt Dawnych w Warszawie [dalej: AGAD], Teki Adama Naruszewicza 11, k. 238-239v. Zob. też M. A. Pieńkowski, Trudna droga, s. 195. Dochody i wydatki skarbu koronnego u progu rządów Zygmunta III i wielką rolę pożyczek omawia A. Filipczak-Kocur, Skarbowość Rzeczypospolitej 1587-1648. Projekty-ustawy-realizacja, Warszawa 2006, s. 69-77. Jak zauważa ta badaczka, na sejmie pacyfikacyjnym wiosną 1589 r. zakwestionowano nawet wydatki na poselstwo P. Uchańskiego jako wydane niezgodnie z konstytucją sejmu koronacyjnego Zygmunta III (s. 74-76).

5 M. Plewczyński, Wojny, t. 3, s. 110-113; J. Wimmer, Wojsko i skarb Rzeczypospolitej u schyłku XVI $i$ w pierwszej połowie XVII wieku, „Studia i Materiały do Historii Wojskowości” 1968, t. 14, s. 9-11 i s. 88 (tabela), gdzie autor wylicza wzrost całości sił zbrojnych po mobilizacji w 1589 r. w stosunku do roku poprzedniego z 3,6 tys. do ok. 15 tys. ludzi (kwarcianych z 2 tys. do 3580).

6 R. Heidenstein, Dzieje Polski od śmierci Zygmunta Augusta do roku 1594, przeł. M. Gliszczyński, red. J. Byliński, W. Kaczorowski, Opole 2015, s. 590-591; H. Wisner, Dyplomacja polska w latach 15721648, [w:] Historia dyplomacji polskiej, red. G. Labuda, t. 2, Wrocław 1982, s. 71-72. 
Pierwsze wieści o możliwym zatargu zbrojnym przychodziły do hetmana polnego koronnego Stanisława Żółkiewskiego już na początku $1590 \mathrm{r}^{7} \mathrm{~W}$ tym czasie w Warszawie zebrał się sejm, obradujący od 8 marca do 21 kwietnia $1590 \mathrm{r}$. Kanclerz i hetman wielki koronny Jan Zamoyski wygłosił 20 marca wobec stanów Rzeczypospolitej płomienną mowę, wskazującą na zagrożenie osmańskie. Posiłkował się przy tym alarmującymi listami, które zdążył wysłać jeszcze Paweł Uchański. Oliwy do ognia dolało przybycie Mikołaja Czyżewskiego i przedstawienie przezeń żądań osmańskich. Hetman wielki zręcznie wykorzystał poruszenie wśród obradujących i w kolejnej mowie, jaką wygłosił 12 kwietnia, przekonał słuchaczy o realnej groźbie wojny z Osmanami. W ślad za tym uzyskał zgodę na bezprecedensowe uchwały obronne. Sejm postanowił zaciągnąc kilkadziesiąt tysięcy wojska — więcej niż Stefan Batory prowadził przeciw Moskwie - którego utrzymanie szacowano na 3,6 mln zł. Do udziału w wojnie zobowiązano także Litwę. Hetmanowi wielkiemu koronnemu dano szerokie uprawnienia jako wodzowi i dyplomacie, mogącemu negocjować warunki porozumienia z Osmanami. Kozaków ujęto w karby, uchwalając nową konstytucję „Porządek ze strony Niżowców i Ukrainy”. No i wreszcie zajęto się nervus belli, czyli zabezpieczeniem finansowym spodziewanej wojny. Znów bezprecedensowo uchwalono podatek pogłówny, a także pożyczki ${ }^{8}$.

Jednym z elementów przygotowań wojennych było też znalezienie sojuszników do walki z Osmanami. Liczono przede wszystkim na pomoc finansową, gdyż zaangażowania się zbrojnego państw chrześcijańskich do wspólnej walki z islamem nikt chyba poważnie nie brał pod uwagę. Jeszcze najłatwiej można by pewnie było pozyskać do tego Moskwę, ale stosunki z nią od czasów wojen bałtyckich za ostatniego Jagiellona i Stefana Batorego nie były najlepsze. Dyplomacja polska skupiła się zatem na tradycyjnych filarach chrześcijaństwa - Stolicy Apostolskiej i Cesarstwie. Starano się także o pomoc u poszczególnych książąt Rzeszy oraz związanych z Koroną Prus Książęcych. Zabiegi dyplomatyczne nad Tybrem rozszerzono też na inne państwa włoskie.

Akcję dyplomatyczną w Rzymie podjął rezydujący tam poseł polski Stanisław Reszka. Otrzymał on zadanie skontaktowania się nie tylko ze Stolicą Apostolską, ale i rezydującymi przy niej posłami cesarza i państw włoskich. Reszka uzyskał 25 maja 1590 r. audiencję u papieża Sykstusa V, która nie przyniosła oczekiwanych efektów. Papież nie docenił niebezpieczeństwa osmańskiego, a rozmowy o ewentualnej po-

7 Hetman polny przesyłał je hetmanowi wielkiemu, który z kolei informował o niebezpieczeństwie króla: J. Zamoyski do Zygmunta III, Sokal, 12.02.1590, AGAD, Archiwum Zamoyskich, sygn. 126, s. 5860; tenże do tegoż, Sokal, 17.02.1590, ibidem, s. 62-67 (kopia).

8 K. Lepszy, Rzeczpospolita Polska w dobie sejmu inkwizycyjnego (1589-1592), Oświęcim 2015 (reedycja), s. 108-127; M. A. Pieńkowski, Kwestia wojny z Turcją na sejmie warszawskim 1590 roku, [w:] Studia historyczno-wojskowe, t. 6, red. K. Maksymiuk i inni, Siedlce 2015, s. 26-32; J. Wimmer, Wojsko i skarb, s. 11. Suma pożyczek na wojnę sięgnęła 65,5 tys. złotych; A. Filipczak-Kocur, Skarbowość Rzeczypospolitej, s. 79-81. 
mocy odłożył do czasu przybycia do Rzymu posła wielkiego 9 . Było to zapewne niemiłym zaskoczeniem dla strony polskiej, która mogła więcej spodziewać się po papieżu, starającym się - mimo sympatii prohabsburskich — dochować neutralności w dobie ostatniego bezkrólewia ${ }^{10}$. Od pomocy wymówił się także poseł wenecki w Rzymie, który zasłaniał się brakiem gotowości Republiki św. Marka i ewentualnym zagrożeniem osmańskim w przypadku jej zaangażowania się w pomoc Polsce ${ }^{11}$. Zapewne w podobnym duchu odpowiedział książę mantuański, którego poseł wręczył list Stanisławowi Reszce 1 czerwca. Z kolei poseł cesarski w Rzymie widział szansę na współpracę, ale tylko w przypadku, gdyby już doszło do wojny osmańskopolskiej i Rzeczpospolita odniosłaby w niej pierwsze znaczące zwycięstwo, bo teraz każdy pod jego [Turka - D.M.] straszna moca jako przepiórka pod jastrzębiem się uchyla. Tymczasem zaś pocieszał Polaków niesprawdzonymi wieściami o rzekomej klęsce tureckiej w wojnie z Persją i związanym z tym nieprawdopodobieństwem wszczęcia wojny przeciw Polsce ${ }^{12}$.

Jak zatem widać, akcja dyplomatyczna podjęta w Italii przez sekretarza królewskiego Stanisława Reszkę zakończyła się niepowodzeniem, nie przynosząc Polsce niczego oprócz gołosłownych deklaracji życzliwości i pocieszeń. Może i trudno dziwić się Sykstusowi V, który po świeżym zatargu polsko-habsburskim mógł nie dowierzać w realność współpracy obu państw, bez której i pomoc papieska byłaby niewiele znacząca. Rzym miał zresztą wówczas własne kłopoty na Zachodzie, będąc zaangażowany w wojnę domową we Francji — przypomnijmy, że papież ekskomunikował króla

9 S. Reszka do Zygmunta III, Rzym, 26.05.1590, [w:] Starożytności historyczne polskie, wyd. A. Grabowski, t. 2, nr 1, Kraków 1840 [dalej: A. Grabowski, Starożytności], s. 358-359. W liście do kanclerza S. Reszka domyślał się, że na dworze papieskim ktoś nieżyczliwy Polsce umyślnie w złym świetle przedstawia niebezpieczeństwo tureckie - S. Reszka do J. Zamoyskiego, Rzym, 26.05.1590, ibidem, nr 2, s. 366.

10 Wbrew intencjom Sykstusa V postępował wówczas jego nuncjusz w Polsce Annibale di Capua, jawnie wręcz sprzyjający Habsburgom, niemniej papież szybko uznał Zygmunta III, a misja legata Ippolita Aldobrandiniego w latach 1588-1589 była dowodem papieskiej życzliwości dla Polski zob. D. Gregorowicz, Tiara w grze o koronę. Stolica Apostolska wobec wolnych elekcji w Rzeczypospolitej Obojga Narodów w drugiej połowie XVI wieku, Kraków 2019, s. 106-109, 142-154 i 190-211 (misja Aldobrandiniego) oraz A. Barwicka-Makula, Od wrogości do przyjaźni. Habsburgowie austriaccy wobec Polski w latach 1587-1592, Katowice 2019, s. 178-278 (autorka zwraca uwagę, że papież odmówił Habsburgom powierzenia mediacji Annibalowi di Capua, zaś Aldobrandini walnie przyczynił się do rozwiązania korzystnego dla Polski).

11 Co się tknie pomocy i ratunku pieniężnego na wojnę, on to wszytko ogładzat dtugo mówiac, w jakiem też sami sq niebezpieczeństwie od tegoż nieprzyjaciela; jakie nań oko musza mieć. Jednak summa wszytkiego byla, że na ten czas nie tak sa gotowi i nie tak bezpieczni od Turka, by się mogli W.K.Mci pieniędzmi zachować; S. Reszka do Zygmunta III, Rzym, 26.05.1590, [w:] A. Grabowski, Starożytności, t. 2, nr 2, s. 360. O zasadniczo pokojowej polityce weneckiej wobec Osmanów w końcu XVI w. zob. G. Poumarède, L'Empire de Venise et les Turcs XVI $-X V I I^{e}$ siècle, Paris 2020, s. 145-161 (ogólne założenia polityczne) i 183-185.

12 S. Reszka do J. Zamoyskiego, Rzym, 26.05.1590, [w:] A. Grabowski, Starożytności, t. 2, nr 2, s. 366-367 (tu cytat); tenże do Zygmunta III, Rzym, 02.06.1590, ibidem, nr 2, s. 361. Zabiegi czynione przez dyplomację polską w państwach włoskich przedstawił H. Wisner, Dyplomacja polska, s. 72. 
Henryka III za jego sojusz z Henrykiem Burbonem i nie uznawał tego ostatniego za króla po śmierci Walezjusza w sierpniu 1589 r. Chyba wręcz wygodniej było papiestwu przymknkąć oczy na zagrożenie osmańskie wobec Polski i mieć nadzieję, że do wojny nie dojdzie.

Zdaje się też, że Zygmunt III więcej spodziewał się po bezpośredniej interwencji u cesarza, książąt Rzeszy i lennika pruskiego. W dobie rodzących się planów przekazania korony polskiej Habsburgom — abstrahując przy tym, na ile realnie król traktował ten projekt — można wszak było żywić nadzieję na Wawelu, że cesarz nie odmówi pomocy sąsiadowi, z którym świeżo się pojednał. Przyjrzyjmy się zatem zabiegom królewskim o pomoc cesarską.

Pierwszy raz Zygmunt III zasygnalizował Rudolfowi II sprawę zagrożenia osmańskiego wobec Polski już w lutym 1590 r. w liście dotyczącym zasadniczo sprawy niezaprzysiężenia traktatów będzińsko-bytomskich przez arcyksięcia Maksymiliana ${ }^{13}$. Król nader zręcznie przedstawiał siebie w roli życzliwego sąsiada, wyciągającego rękę do zgody. Choć bowiem ubolewał nad oporem brata cesarskiego wobec dopełnienia warunków jego uwolnienia z polskiej niewoli, to jednak wyrażał mocne przekonanie, że nie powinno to przeszkodzić w pełnej normalizacji stosunków między Krakowem a Pragą. Zygmunt wzmacniał swój autorytet przywołując również swego ojca, króla szwedzkiego Jana III i przypominając o poczynionych z nim uzgodnieniach na zjeździe rewelskim. Podkreślenie współdziałania ojca i syna miało bez wątpienia podnieść rangę króla polskiego i całej dynastii wazowskiej jako liczących się graczy na scenie politycznej Europy.

Tak przygotowawszy grunt, Zygmunt III postawił sprawę zagrożenia osmańskiego, pisząc o ciężkiej wojnie, jaką zamyślają przeciw niemu Turcy i Tatarzy (gravissimum a Turcis et Tartaris bellum Regno nostro intentabatur). W kontekście tego zagrożenia król polski postulował konieczność porozumienia z cesarzem, przez co należy rozumieć $\mathrm{w}$ pierwszej kolejności załatwienie sprawy przysięgi arcyksięcia Maksymiliana.

Czytając ten list, wysłany z Warszawy 7 lutego 1590 r., nie widzimy jeszcze, by król odczuwał realne zagrożenie ze strony Osmanów. Na pismo królewskie trzeba patrzeć też w kontekście wysłanych tego samego dnia listów do innych członków rodziny Habsburgów, w tym brata cesarskiego arcyksięcia Ernesta oraz do arcyksięcia Ferdynanda hrabiego Tyrolu ${ }^{14}$. Jak wiadomo, młodszy brat Rudolfa II był raczej życzliwy królowi polskiemu i optował za wyciszeniem zatargu, podsycanego uporem arcyksięcia Maksymiliana, podczas gdy stryj cesarski Ferdynand sekun-

13 Zygmunt III do Rudolfa II, Warszawa, 07.02.1590, [w:] The House of Vasa and The House of Austria. Correspondence from the Years 1587 to 1668, cz. 1 (The Times of Sigismund III, 1587-1632. Volume 1), wyd. R. Skowron i inni, Katowice 2016, nr 9, s. 229-230.

14 Zygmunt III do arcyks. Ernesta, Warszawa, 07.02.1590, [w:] The House of Vasa and The House of Austria, nr 10, s. 231 i tenże do arcyks. Ferdynanda, Warszawa, 07.02.1590, ibidem, nr 11, s. $232-233$. 
dował poczynaniom Zygmuntowego rywala do tronu polskiego ${ }^{15}$. W każdym razie obu tych wpływowych członków rodziny cesarskiej Zygmunt III starał się przekonać do wywarcia wpływu na Maksymiliana, aby zaprzysiągł zrzeczenie się praw do korony polskiej. W żadnym z tych listów nie ma mowy o zagrożeniu osmańskim dla Polski. Także w odpowiedziach udzielonych królowi polskiemu na przełomie marca i kwietnia nie wspomina się nic o Turkach, koncentrując na sprawie przysięgi arcyksięcia Maksymiliana ${ }^{16}$. Sam cesarz zdecydował się wówczas wysłać do Polski Daniela Prinza jako swego oficjalnego posła, zlecając mu przede wszystkim niedopuszczenie do podjęcia przez sejm antyhabsburskich postanowień, w tym ekskluzji Habsburga od tronu. Jak wiadomo, misja ta — wobec wrogiej królowi postawy arcyksięcia Maksymiliana i spóźnionego przyjazdu posła — zakończyła się niepowodzeniem ${ }^{17}$. Nie wróżyło to najlepiej perspektywom ewentualnej współpracy polsko-habsburskiej przeciw Osmanom.

Nie ulega więc wątpliwości, że na początku lutego 1590 r. Zygmunt III czysto instrumentalnie wykorzystywał wobec Habsburgów pogłoski o możliwej wojnie z Osmanami, używając tego jako argumentu dla uzyskania ważniejszego w tym momencie celu, jakim było zaprzysiężenie przez arcyksięcia Maksymiliana traktatów będzińsko-bytomskich ${ }^{18}$. Pisał zresztą o Turkach tylko do cesarza, który z racji sprawowanej władzy mógł i powinien być zainteresowany ewentualną wojną swoich sąsiadów. Takie zachowanie króla jest oczywiście zrozumiałe, jako że w tym czasie można było raczej mówić o rosnącym napięciu między Stambułem a Krakowem, podsycanym przez niepewne informacje i plotki, docierające choćby do obu hetmanów koronnych niż o realnej groźbie wojny. Ta — jak pamiętamy — stanęła przed oczyma polskich polityków dopiero w marcu 1590 r., gdy przyszły listy od posła polskiego w Stambule i od samego sułtana.

Wraz z tym faktem Zygmunt III postanowił podjąć rzeczywistą próbę uzyskania pomocy cesarskiej, przy czym mógł wykorzystać wcześniejszą wzmiankę o niebezpieczeństwie osmańskim jako zapowiedź urzeczywistaniającej się groźby. Jeszcze przed zakończeniem sejmu władca postanowił wysłać swego sekretarza Jana Szczęsnego Herburta do Pragi i świeckich elektorów w Rzeszy: saskiego Chrystiana I Wettyna, brandenburskiego Jana Jerzego I Hohenzollerna i regenta palatynatu reńskiego Jana Kazimierza Wittelsbacha, sprawującego rządy w imieniu małoletnie-

15 Jakkolwiek sam Ferdynand Tyrolski zaprzysiągł traktaty będzińsko-bytomskie i jesienią 1589 r. dystansował się od pomysłów wojny z Polską, to zarazem nie namawiał arcyksięcia Maksymiliana do złożenia wymaganej odeń przysięgi; A. Barwicka-Makula, Od wrogości do przyjaźni, s. 290.

16 Ferdynand Tyrolski do Zygmunta III, Innsbruck, 22.03.1590, [w:] The House of Vasa and The House of Austria, nr 12, s. 234; arcyks. Ernest do tegoż, Praga, 27.03.1590, ibidem, nr 13, s. 235; Rudolf II do tegoż, Praga, 02.04.1590, ibidem, nr 14, s. 236; arcyks. Karol Styryjski do tegoż, Graz, 03.04.1590, ibidem, nr 15, s. 237; arcyks. Maciej do tegoż, Wiedeń, 09.04.1590, ibidem, nr 17, s. 240-241.

17 K. Lepszy, Rzeczpospolita Polska, s. 127-131; A. Barwicka-Makula, Od wrogości do przyjaźni, s. 301-306.

18 A. Barwicka-Makula, Od wrogości do przyjaźni, s. 299. 
go elektora Fryderyka IV. Posła zaopatrzono w listy datowane z Warszawy 6 kwietnia $1590 \mathrm{r}$. Było to — jak pamiętamy — jeszcze przed przyjazdem na sejm posła cesarskiego Daniela Prinza z generalnie rozczarowującą rezolucją na żądania w sprawie przysięgi arcyksięcia Maksymiliana. Nieudana misja Prinza wywołała nowe oziębienie w stosunkach polsko-habsburskich, którego wyrazem była stanowcza odpowiedź króla na poselstwo, zredagowana zresztą przez święcącego wówczas tryumfy polityczne kanclerza Jana Zamoyskiego ${ }^{19}$. To jednak nastąpiło dopiero w końcu kwietnia, podczas gdy na początku tego miesiąca Zygmunt III mógł mieć jeszcze nadzieję na współpracę z cesarzem przeciw Osmanom.

Przyjrzyjmy się zatem, w jaki sposób król polski chciał osiągnąc ten cel. W liście do cesarza wyraził przede wszystkim swoje niezadowolenie z powodu niedopełnienia przez arcyksięcia Maksymiliana traktatowego obowiązku przysięgi. Można by to uznać za niepotrzebne drażnienie potencjalnego sojusznika, wydaje się jednak, że król miał inny zamiar. Szło raczej o przypomnienie cesarzowi zobowiązania, jakie winien jest Zygmuntowi III, aby tym bardziej uwypuklić dobrą wolę króla polskiego i skłonić cesarza do współpracy jako formy rekompensaty. O tym, że taki był tok rozumowania króla, świadczy płynne przejście do informacji o zagrożeniu osmańskim i powiązanie jej z panującą dotychczas niezgodą pomiędzy Pragą a Krakowem. Zygmunt III wprost pisze, iż szykuje się do wojny z Turkami, będącymi nieprzyjaciółmi całego chrześcijańtwa. Wobec tej groźby król oczekuje, że cesarz zaniecha sporów z Polską - a więc wreszcie skłoni swego brata do zaprzysiężenia traktatów będzińsko-bytomskich — i co więcej, udzieli jej pomocy przeciw Osmanom. Chodziło przy tym królowi tak o posiłki w wojsku i zaopatrzeniu wojennym, jak i o pomoc finansową, która ułatwiłaby zaciąganie wojska i nie obligowała cesarza do rozpoczynania wojny z Imperium Osmańskim. Król podkreślał też obowiązki cesarza w zakresie obrony wiary — jako pierwszego spośród władców chrześcijańskich - i liczył na jego autorytet, który ułatwiłby uzyskanie pomocy od innych władców ${ }^{20}$.

Argumentacja polska zmierzała zatem do wzbudzenia w cesarzu poczucia winy, jaką miało być faktyczne podsycanie niepokojów w Rzeczypospolitej, a co najmniej utrudnianie jej pacyfikacji, gdy zwolennicy Maksymiliana wciąż mogli na niego

19 Zygmunt III do Rudolfa II, Warszawa, 26.04.1590, [w:] The House of Vasa and The House of Austria, nr 18, s. 242; A. Barwicka-Makula, Od wrogości do przyjaźni, s. 307.

20 Ad bellum nos paramus; a Maiestate Vestra diligenter petimus, ut si et ipsius serenissimae familiae suae causa in discrimen hoc adductos fere nos intelligat, quod magis autem est, universae christianitatis periculum agi perspiciat, non modo de eis, quae antea desideravimus nobis Regnoque nostro eo citius satisfaciendum curet, sed in communi periculo pro eo loco, quem inter principes christianos tenet, ipsa quoque non tam nobis, quam universae christianitati cum pecuniario aliquot subsidio, tum consilio atque auctoritate sua non desit; maxime vero quo ex Sacro Romano Imperio tum Maiestatis et vestris ditionibus auxilia, arma, instrumentum et commeatum bellicum petere nobis liceat, auctoritatem suam nobis praestet, rogamus. Zygmunt III do Rudolfa II, Warszawa, 06.04.1590, [w:] The House of Vasa and The House of Austria, nr 16, s. 238-239. 
liczyć. Na tym tle przypominano Rudolfowi II o jego cesarskich obowiązkach obrony chrześcijaństwa i formułowano konkretne postulaty, których — jak zaznaczono w liście - właśnie od cesarza miał prawo domagać się król, zagrożony przez muzułmanów. Podkreślając dalej, że sam czyni co może dla przygotowania się do wojny, będącej w interesie całego chrześcijaństwa, Zygmunt III prosił o życzliwe przyjęcie posła polskiego, spodziewając się realizacji przedłożonych przezeń postulatów.

Analizując treść i sposób argumentacji stosowanej w liście królewskim do cesarza, możemy przypuszczać, że Zygmunt III spodziewał się w najlepszym razie załatwić obie interesujące go sprawy: zaprzysiężenie traktatów będzińsko-bytomskich przez Maksymiliana i taką czy inną pomoc przeciw Osmanom. W pierwszej kwestii król rozwinął poniekąd argumentację, użytą już w lutym: przywołując zagrożenie osmańskie sugerował, że nie wypada wręcz w takiej sytuacji utrudniać Rzeczypospolitej życia absorbowaniem jej uwagi sprawą roszczeń arcyksięcia. $Z$ drugiej strony chciał wygrać psychologicznie habsburską zwłokę w dopełnieniu warunków porozumienia z Polską i przymusić cesarza do okazania jej życzliwości - czy to poprzez pomoc przeciw Osmanom, czy w ostateczności poprzez zamknięcie sprawy Maksymiliana.

Jak się wszakże miało okazać, nie przyniosło to spodziewanych efektów. Poseł polski został przyjęty przez Rudolfa II 7 maja i niecały tydzień później odprawiony z wymijającą odpowiedzią ${ }^{21}$. W sprawie Maksymiliana cesarz nie chciał dodać nic nowego, czego by nie zlecił wysłanemu do Polski posłowi. Szerzej rozpisał się na temat zagrożenia tureckiego. Ubolewał nad nim i doradzał królowi zawarcie pokoju z sułtanem. Sam też wymawiał się od jawnego włączenia się do konfliktu, powołując się na obowiązujący go traktat pokojowy z Portą. Nie omieszkał także wypomnieć królowi działań sejmu, który z inicjatywy kanclerza Jana Zamoyskiego omawiał sprawę wykluczenia Habsburgów od kandydowania do tronu polskiego. Miał to być w zamierzeniu Polaków środek nacisku na cesarza, by wymusić wreszcie złożenie przysięgi przez arcyksięcia Maksymiliana. Rzecz była oczywiście doskonale znana w Pradze i między innymi podjęciu takiej właśnie uchwały miał zapobiec Daniel Prinz. Tymczasem wszakże cesarz wykorzystał tę sprawę jako dowód nieprzychylności Polski dla niego i całego domu austriackiego, a zatem i pretekst do wymówienia się od udzielenia Rzeczypospolitej pomocy przeciw Turkom.

Poniekąd można było się tego spodziewać. Cesarz miał związane ręce misją Daniela Prinza, z którym rozminął się Jan Szczęsny Herburt. Co więcej, w Pradze wciąż łudzono się nadziejami na rychłe zawakowanie tronu polskiego i Rudolf II nie bardzo chciał naciskać brata w sprawie przysięgi. Kluczył on zresztą pomiędzy roszczeniami i żądaniami Maksymiliana a perspektywami zrzeczenia się tronu polskiego

21 Rudolf II do Zygmunta III, Praga, 13.05.1590, [w:] The House of Vasa and The House of Austria, nr 19, s. 243. W tym liście cesarz informował króla o odprawieniu posła wraz z pisemną odpowiedzią, której treść: Decretum, quo ad Joannis Felicis Herburti a Fulstain, serenissimi Poloniae Regis Secretarii, Legationem respondetur, [w:] Divi Rudolphi II Imperatoris, Caesarii Augusti Epistolae Ineditae: Desumptae Ex Codice Manu Exarato Caesareo Classis Jur. Civ., wyd. B. Pace, Viennae 1771, s. 212-216. 
na rzecz Ernesta, którymi kusił Habsburgów Zygmunt III. W efekcie cesarz nie potrafił zdecydować się na żadne konkretne działanie. Dotyczyło to również pomocy Polsce przeciw Osmanom. Bez wątpienia Rudolf II udzieliłby jej, gdyby Maksymilian albo Ernest objęli tron w Krakowie. Wsparcie Zygmunta III było raczej mało opłacalne, a co więcej — dwór praski mógł mieć nadzieję, że groźba nawały osmańskiej skłoni wreszcie króla polskiego do opuszczenia kraju, a samych Polaków pchnie w ramiona Habsburgów jako ostatniej deski ratunku. Tymczasem zaś Rudolf II nie dał się zaszantażować moralnie sprawą Maksymiliana, ale wysuwając samemu projektowaną ekskluzję Habsburgów od korony polskiej, zasłonił się tą urazą od udzielenia pomocy. W domyśle dał Polakom do zrozumienia, że nie mają co liczyć na sukurs austriacki, dopóki nie zmienią swej antyhabsburskiej polityki.

Podsumowując, możemy stwierdzić, że obie strony starały się wykorzystać osmański straszak do załatwienia własnych spraw, a przede wszystkim kwestii panowania w Polsce. Była to sytuacja nader sprzyjająca dla Osmanów i bez wątpienia ułatwiłaby im działanie, gdyby w 1590 r. zdecydowali się na wojnę z Rzecząpospolitą.

Bynajmniej nie lepszy skutek przyniosły zabiegi królewskie o pomoc przeciw Turkom, czynione u margrabiego brandenburskiego Jana Jerzego Hohenzollerna. Król powiadomił go o wypowiedzeniu Polsce wojny przez sułtana i prosił o stosowną pomoc. Przedstawił przy tym najazd tatarski z 1589 r. jako preludium do wojny. Opisał najnowsze przygotowania wojenne Osmanów w rejonie Dunaju, jak też własne zabiegi dla utrzymania pokoju — a więc misję Pawła Uchańskiego, doznane przezeń zniewagi i śmierć w Stambule. Podobnie jak w liście do cesarza, król wskazywał na niemożność samodzielnego odparcia najazdu przez Polskę oraz zagrożenie dla całego chrześcijaństwa. Zręcznie podnosił przy tym męstwo książąt Rzeszy, a wśród nich margrabiego brandenburskiego, oczekując odeń — i innych książąt — najpierw pieniędzy, następnie posiłków wojskowych, wreszcie armat, prochu i wszelkiego zaopatrzenia wojennego. Największy nacisk król kładł na pomoc pieniężną. Co do wojska, prosił tak o oddziały niemieckie, jak i o możliwość rekrutowania w posiadłościach margrabiego. Prosił też Hohenzollerna o nakłanianie innych książąt do pomocy Polsce, utyskując na opóźnianie sprawy u Habsburgów w związku z niezaprzysiężeniem traktatów będzińsko-bytomskich przez Maksymiliana. Król podkreślał wreszcie konieczność szybkiego działania ${ }^{22}$.

Poseł polski musiał udać się do Brandenburgii po odprawie u cesarza, gdyż odpowiedź wystosowano z datą 11 maja starego stylu (21 maja), a więc w dwa tygodnie po audiencji Jana Szczęsnego Herburta u Rudolfa II w Pradze. Margrabia ubolewał nad zagrożeniem wiszącym nad Polską i całym chrześcijaństwem i życzył pokonania Turków z pomocą Bożą. Co do pomocy własnej, zasłaniał się pilnymi potrzebami samej Rzeszy, w tym zagrożeniem Węgier ze strony Osmanów. Uważał, że sprawa wymaga omówienia na forum Rzeszy, co oczywiście oznaczało zwłokę i pozwala-

22 Zygmunt III do Jana Jerzego, Warszawa, 06.04 .1590 r., Geheimes Staatsarchiv Preußischen Kulturbesitz w Berlinie (dalej: GStA PK), I Hauptabteilung (dalej: I HA), Rep. 9 Polen, nr 2a B, k. $71-$ $73 \mathrm{v}, 77$. 
ło tymczasem wymówić się od udzielenia konkretnej pomocy. Oczywiście zapewniał, że dołoży wszelkich starań dla pozyskania książąt Rzeszy dla sprawy wsparcia Polski. Koił też niepokój Zygmunta III w sprawie królewskich ambicji arcyksięcia Maksymiliana ${ }^{23}$.

Co ciekawe, do margrabiego brandenburskiego napisał też osobiście kanclerz i hetman wielki koronny Jan Zamoyski. Polecał on Szczęsnego Herburta jako swego bliskiego współpracownika (propinquum meum), prosząc, aby przez wzgląd na kanclerza margrabia udzielił mu szybszego posłuchania ${ }^{24}$.

Warto też zauważyć, że w archiwum berlińskim znajdują się łacińskie kopie listów tureckich: Murada III do Zygmunta III, datowane 18 lutego, 7 maja i 22 czerwca 998 H (1590 r.) oraz Hedera paszy do Jana Zamoyskiego z tegoż samego roku ${ }^{25}$. Być może dołączono je bądź przysłano później dla wzmocnienia argumentacji o realnym zagrożeniu osmańskim. Polacy starali się wobec elektora zinterpretować treść żądań osmańskich jako faktyczne wypowiedzenie wojny.

Nie są mi znane materiały dotyczące misji Jana Szczęsnego Herburta u elektorów Saksonii i Palatynatu. Mogę jedynie domniemywać, że sekretarz królewski odwiedził dwór Chrystiana I Wettyna w drodze z Pragi do Berlina. Interesującym wątkiem jest natomiast próba znalezienia pomocy u polskiego lennika - Prus Książęcych — oraz administrującego nimi w zastępstwie chorego umysłowo księcia Fryderyka Albrechta margrabiego Ansbachu Jerzego Fryderyka Hohenzollerna i urzędującego w Królewcu kolegium nadradców pruskich.

Zygmunt III już 26 marca 1590 r. zawiadomił margrabiego ansbachskiego o grożącym Polsce niebezpieczeństwie tureckim, zwracając uwagę m.in. na działania Tatarów i bejlerbeja oczakowskiego (sylistryjskiego) ${ }^{26}$. Już w dniu 13/23 kwietnia Jerzy Fryderyk odpowiedział królowi na poselstwo Jana Szczęsnego Herburta, który - jak z tego wynika - musiał dotrzeć do margrabiego Ansbachu jeszcze zanim uzyskał posłuchanie u cesarza. Margrabia dziękował za przedstawienie przez posła niebezpieczeństwa tureckiego i nie szczędził zapewnień o chrześcijańskiej solidarności tudzież życzeń, by Bóg poskromił zapędy tureckiego „tyrana”. Wyrażał też przekonanie, że cesarz i elektorzy nie odmówią królowi żądanej przezeń pomocy tak w pieniądzu, jak i w możliwości werbunku żołnierza. Co do żądań kierowanych pod

23 Jan Jerzy do Zygmunta III, Cölln [Kolonia nad Szprewą], 11/21.05.1590 r. (koncept odpowiedzi), GStA PK, I HA, Rep. 9 Polen, nr 2a B, k. 74-76.

24 J. Zamoyski do Jana Jerzego, Warszawa, 06.04.1590 r., GStA PK, I HA, Rep. 9 Polen, nr 2a B, k. 69-70. O związkach Herburta z kanclerzem zob. W. Tygielski, Listy, ludzie, władza. Patronat Jana Zamoyskiego w świetle korespondencji, Warszawa 2008, s. 47-48, 86-87.

${ }^{25}$ Murad III do Zygmunta III, Stambuł, 18.02.998 H [1590], GStA PK, I HA, Rep. 9 Polen, nr 2a B, teczka Februar 1590, k. 3-9v (inna kopia: ibidem, teczka bez opisu, k. 169-173v); tenże do tegoż, Stambuł, 07.05.998 H [1590], ibidem, teczka Mai 1590, k. 143-145; tenże do tegoż, Stambuł, 22.06.998 H [1590], ibidem, teczka Juni-August 1590, k. 147-148v; Heder pasza do J. Zamoyskiego, Silistria, 998 H [1590], ibidem, teczka April 1590, k. 44-44v.

26 Zygmunt III do margrabiego Jerzego Fryderyka, Warszawa, 26.03.1590, GStA PK, XX Hauptabteilung — Staatsarchiv Königsberg [dalej: XX HA], Etats Ministerium [dalej: EM], 111m, nr 13, k. 20-22. Inne kopie: ibidem, nr 15, k. 3-5v i 7-9. 
własnym adresem, deklarował chęć ich spełnienia. W pierwszej kolejności zgodził się, by jego poddani zaciągali się do wojska polskiego, przy czym musimy przez to rozumieć mieszkańcow Prus Książęcych. Sam wszakże wymówił się od osobistego udziału w wojnie. Nie palił się też do zasilenia króla w armaty, proch i kule, narzekając, że sam ma ich mało i przypominając, że pożyczył swego czasu działa Stefanowi Batoremu i do tej pory ich nie odzyskał. Podobnie wymawiał się od udzielenia żądanej pomocy finansowej, deklarując wszak, iż postara się uzyskać jakąś sumę (summam aliquam) u swych poddanych — co znów musimy odnieść do Prusaków ${ }^{27}$.

Na mocy postanowień traktatu krakowskiego Prusy Książęce były zobowiązane dostarczyć królowi polskiemu pomoc zbrojną w sile 100 konnych ${ }^{28}$. Było to oczywiście śmiesznie mało w stosunku do potrzeb przewidywanej wojny tureckiej oraz wysiłku militarnego, uchwalonego przez sejm. Zygmunt III miał więc nadzieję uzyskać z Prus dużo bardziej realną pomoc. Do nadradców pruskich król pisał dwakroć w kwietniu $1590 \mathrm{r}$. W pierwszym liście prosił ich o dostarczenie zaopatrzenia wojskowego na potrzebę grożącej wojny z Turkami ${ }^{29}$. W kolejnym liście, datowanym 25 kwietnia, król zawiadamiał nadradców o zleceniu Jerzemu Farensbachowi przeprowadzenia zaciągów wojskowych w Inflantach. Prosił zarazem, by mu nie przeszkadzać, jeżeli zechce prowadzić takie zaciągi także w Prusach Książęcych i w administrowanym przez margrabiego ansbachskiego biskupstwie kurońskim w Inflantach ${ }^{30}$. Do listu załączono kopię uniwersału królewskiego z 23 kwietnia w sprawie wysłania Jerzego Farensbacha dla czynienia zaciągów wojskowych w Inflantach ${ }^{31}$.

Król postanowił też prowadzić osobne zaciągi w księstwie pruskim i powierzył to zadanie kapitanowi Piotrowi (Peterowi) von Hesen. O zgodę na tę akcję prosił Jerzego Fryderyka jeszcze w końcu sierpnia 1590 r. ${ }^{32}$

Powodzeniem zakończyła się akcja pozyskania funduszów od Prusaków. Uzyskawszy zgodę margrabiego Jerzego Frydryka, król wysłał w sierpniu 1590 r. księdza Sebastiana Grabowieckiego, by zbierał w Prusach Książęcych pieniądze na spodziewaną wojnę turecką, o czym zawiadomił nadradców osobnym uniwersałem ${ }^{33}$. Wysłannik był niegdyś dworzaninem Zygmunta Augusta i później sekretarzem kró-

27 Jerzy Fryderyk do Zygmunta III, Ansbach, 13/23.04.1590, GStA PK, XX HA, EM, 111m, nr 13, k. 23-24v. (koncept odpowiedzi).

28 O. Balzer, Corpus iuris Polonici, t. 4/1, Kraków 1910, nr 46, s. 141-159.

29 Zygmunt III do nadradców pruskich, Warszawa, 12 i 25.04.1590, GStAPK, XX HA, Rep. Herzogliches Briefarchiv [dalej: HBA], B1, Kasten 336, obwoluta K 2381.

30 Jerzy Fryderyk otrzymał w 1585 r. jako zastaw starostwo piltyńskie, obejmujące obszar dawnego biskupstwa kurońskiego — zob. B. Dybaś, Powiat piltyński w XVII w. - jego geneza i status w Rzeczypospolitej, „Czasopismo Prawno-Historyczne” 2003, t. 55, nr 1, s. 204-208.

31 Zygmunt III do nadradców pruskich, Warszawa, 25.04.1590, GStA PK, XX HA, HBA, B1, Kasten 336, obwoluta K 2378.

32 Zygmunt III do Jerzego Fryderyka, Warszawa, 28.08.1590, GStA PK, XX HA, HBA, B1, Kasten 336, obwoluta K 2371.

33 Zygmunt III do nadradców pruskich, Warszawa, 16.08.1590, GStA PK, XX HA, HBA, B1, Kasten 336, obwoluta bez numeru. Kopie uniwersału: GStA PK, XX HA, EM, 111m, nr 13, k. 43-43v i 45-45v. 
lewskim — niebawem miał zostać opatem cystersów w Bledzewie, być może właśnie za zasługi w dyplomacji. Co prawda jesienią i zimą 1590/1591 r. niebezpieczeństwo osmańskie było już mało realne, ale Zygmunt III raz dostawszy zgodę na zebranie zasiłku finansowego w Prusach, nie zamierzał z niego rezygnować. Pisał w tej sprawie do nadradców jeszcze w styczniu i lutym 1591 r. ${ }^{34}$ Najwyraźniej nie byli oni zbyt chętni do udzielenia pomocy, skoro w sprawę wmieszał się także margrabia ansbachski, interweniując na przełomie stycznia i lutego u nadradców w kwestii misji S. Grabowieckiego ${ }^{35}$. Stanowisko nadradców poznajemy z ich odpowiedzi, jakie w tym samym czasie udzielili królowi i jego posłowi: zapewniając o swej życzliwości, zdawali się całkowicie na wolę księcia, wyrażoną przez jego posłów, wysłanych na sejm do Warszawy ${ }^{36}$. W końcu lutego 1591 r. król wysłał wreszcie do Prus jako posła Reinholda Heidensteina, by dokończył sprawę zaczętą przez S. Grabowieckiego ${ }^{37}$. Wystąpił on wobec kolegium nadradców 9 marca $^{38}$. Na wszelki wypadek interweniował też u margrabiego Jerzego Fryderyka, uzyskując od niego odpowiedź w połowie marca $^{39}$. Sam margrabia zresztą również nieco wcześniej pisał w sprawie pomocy Polsce do nadradców ${ }^{40}$. Ostatecznie połączone wysiłki króla polskiego i margrabiego ansbachskiego przyniosły oczekiwany rezultat: 16/26 marca $1591 \mathrm{r}$. zapadła decyzja o udzieleniu Polsce pomocy w wysokości 10 tys. florenów ${ }^{41}$. Wiadomość o tym król otrzymał na początku kwietnia w Krakowie i już w końcu maja dziękował margrabiemu Jerzemu Fryderykowi za przekazane pieniądze na wojnę turecką — przywieźli je posłowie Jan Wittmansdorff i Michał Giese ${ }^{42}$.

Jak widać, mimo zrozumiałej skądinąd niechęci stanów pruskich do łożenia środków finansowych na potrzeby Polski, Zygmuntowi III udało się uzyskać realną po-

34 Zygmunt III do nadradców pruskich, Warszawa, 24.01.1591, GStA PK, XX HA, EM, 111m, nr 16, k. 14v (kopia w j. niemieckim); tenże do tychże, Warszawa, 19.02.1591, ibidem, k. 3-3v (kopia w j. niemieckim).

35 Jerzy Fryderyk do nadradców pruskich, Schwobon, 25.01./04.02.1591, GStA PK, XX HA, EM, $111 \mathrm{~m}, \mathrm{nr} 16, \mathrm{k} .16-18 \mathrm{v}$.

36 Nadradcy pruscy do Zygmunta III, Królewiec, 28.01./07.02.1591, GStA PK, XX HA, EM, 111m, nr 16, k. 95-95v; ciż do S. Grabowieckiego, Królewiec, 29.01./08.02.1591, ibidem, k. 97-98v (koncepty odpowiedzi).

37 Zygmunt III do nadradców pruskich, Warszawa, 27.02.1591, GStA PK, XX HA, HBA, B1, Kasten 336, obwoluta bez numeru.

38 R. Heidenstein do nadradców pruskich, bm. [Królewiec], 27.02./09.03.1591, GStA PK, XX HA, EM, 111m, nr 16, k. 6-12v.

39 Jerzy Fryderyk do R. Heidensteina, bm., 4/14.03.1591, GStA PK, XX HA, EM, 111m, nr 16, k. 1-2v (koncept odpowiedzi).

40 Jerzy Fryderyk do nadradców pruskich, Ansbach, 26.02./08.03.1591, GStA PK, XX HA, EM, $111 \mathrm{~m}, \mathrm{nr} 16, \mathrm{k} .36-38 \mathrm{v}$.

41 Reces w sprawie 10 tys. florenów węgierskich na wypłatę pomocy dla króla polskiego, Królewiec, 16/26.03.1591, GStA PK, XX HA, EM, 111m, nr 17, k. 1-5v; reskrypt w sprawie przesłania pomocy w wysokości 10 tys. florenów węgierskich, GStA PK, XX HA, EM, 111m, nr 18.

42 Zygmunt III do nadradców pruskich, Kraków, 08.04.1591, GStA PK, XX HA, HBA, B1, Kasten 336, obwoluta bez numeru; tenże do Jerzego Fryderyka, Kraków, 25.05.1591, ibidem, obwoluta bez numeru. 
moc finansową właśnie stamtąd. Zawdzięczał to zaangażowaniu się margrabiego Jerzego Fryderyka. Powtórzyła się zatem sytuacja z 1577 r., kiedy to Stefan Batory na próżno zabiegał u Prusaków o wsparcie na wojnę z Gdańskiem, co wykorzystał margrabia Ansbachu, oferując 200 tys. złotych i otrzymując w zamian kuratelę nad Księstwem Pruskim ${ }^{43}$. Margrabia zręcznie wykorzystywał trudną sytuację finansową Rzeczypospolitej, aby dzięki rozmaitym zasiłkom pieniężnym okazać się jej użytecznym. Poparcie żądań królewskich było też poniekąd rekompensatą za zgodę króla na przeniesienie praw sukcesji do Prus na margrabiów brandenburskich $-\mathrm{z}$ którymi Jerzy Fryderyk współpracował. Zygmunt III zgodził się na to wiosną 1589 r. mimo opozycji ze strony części senatorów, w tym prymasa Stanisława Karnkowskiego notabene przeciwnego także nadzywczajnym uchwałom sejmu 1590 r. w sprawie przygotowań do wojny tureckiej ${ }^{44}$. Na tym tle współpraca margrabiego z królem staje się zupełnie zrozumiała. W zamian za pomoc okazaną królowi margrabia uzyskał też wolną rękę w zarządzie Prusami, gdzie on i jego następcy skutecznie thumili opozycję tzw. kwerulantów ${ }^{45}$.

Polskie zabiegi o pomoc militarną bądź finansową przeciw Turkom, czynione $\mathrm{w}$ innych krajach - czy to włoskich, czy niemieckich — nie przyniosły praktycznie żadnych rezultatów. Margrabia brandenburski w grzecznych słowach wymówił się od udzielenia pomocy. Cesarz Rudolf II zachował się niemal wrogo, wypominając Polakom antyhabsburskie działania na sejmie i zapominając o rzeczywistych przyczynach tego stanu rzeczy. Nie musiał też długo czekać na skutki swego postępowania: kiedy w 1593 r. zaczęła się wielka wojna osmańsko-habsburska na Węgrzech, to właśnie dyplomacja habsburska - wspierana przez papiestwo - spotkała się ostatecznie z odmową Rzeczypospolitej w sprawie proponowanego sojuszu przeciw Turkom. Polacy nie omieszkali wówczas wypomnieć cesarzowi jego obojętnej postawy i ciągle niezałatwionej sprawy przysięgi arcyksięcia Maksymiliana ${ }^{46}$.

43 Zobowiązanie Jerzego Fryderyka z 23.12.1577 do wypłacenia 200 tys. zł królowi polskiemu, AGAD, Zbiór Dokumentów Pergaminowych, sygn. 6922.

44 B. Wachowiak, A. Kamieński, Dzieje Brandenburgii-Prus na progu czasów nowożytnych (15001701), Poznań 2001, s. 228-229. Jak wiadomo, sposób podjęcia uchwał wojennych wzburzył szlachtę, a prymas doprowadził do storpedowania części uchwał sejmu w czasie zjazdy szlachty wielkopolskiej w Kole w sierpniu 1590 r. - R. Heidenstein, Dzieje Polski, s. 592-594, M. A. Pieńkowski, Kwestia wojny z Turcja, s. 33-40.

45 B. Janiszewska-Mincer, F. Mincer, Rzeczpospolita Polska a Prusy Ksiązęce w latach 1598-1621, Warszawa 1988, s. 43-47. B. Wachowiak, A. Kamieński, Dzieje Brandenburgii-Prus, s. 233-234 (w kontekście walki o przejęcie Prus przez margrabiów brandenburskich).

${ }^{46} \mathrm{Na}$ temat negocjacji polsko-cesarskich w sprawie sojuszu przeciw Osmanom w latach 90. XVI w. jest bogata literatura. Przykładowo: J. Sas, Układy o Lige przeciw Turkom za Zygmunta III, „Przegląd Powszechny" 1899, t. 16, nr 63, s. 54-71 i 190-211 i nr 64, s. 350-369; A. Barwicka, Rzeczpospolita w planach dyplomacji papieskiej i habsburskiej w okresie wojny austriacko-tureckiej 1593-1606, [w:] Polska wobec wielkich konfliktów w Europie nowożytnej, wyd. R. Skowron, Kraków 2009, s. 297-307; P. Gawron, Jan Zamoyski, kanclerz i hetman wielki koronny, wobec zmagań turecko-habsburskich w latach 1593-1605/6, ibidem, s. 23-47. 
Tymczasem dyplomacji polskiej udało się odnieść sukces na gruncie osmańskim. Jeszcze wiosną 1590 r. wysłano do Stambułu nowego posła, którym został cześnik łomżyński Jan Zamoyski. Z pewnością jego misji pomagały wiadomości o czynionych w Rzeczypospolitej przygotowaniach obronnych. Uzyskał on też wsparcie angielskiego dyplomaty Edwarda Burtona, jak i doczekał zmiany na stanowisku wielkiego wezyra. Urząd ten objął latem $1591 \mathrm{r}$. Ferhad pasza, bardziej pokojowo nastawiony niż jego poprzednik Kodża (Koca) Sinan pasza. W efekcie udało się wynegocjować traktat pokojowy, który sułtan Murad III zaakceptował w październiku $1591 \mathrm{r}^{47}$ Groźba wojny osmańsko-polskiej została definitywnie zażegnana. W ten sposób spełniło się życzenie Sykstusa V, wypowiedziane wobec Stanisława Reszki — choć sam papież już tego nie doczekał.

\section{BIBLIOGRAFIA}

\section{Źródla archiwalne}

Archiwum Glówne Akt Dawnych w Warszawie:

Archiwum Zamoyskich: 126

Teki Adama Naruszewicza: 11

Zbiór Dokumentów Pergaminowych: 6922

Geheimes Staatsarchiv Preußischen Kulturbesitz w Berlinie:

I Hauptabteilung. Geheimer Rat, Repositur 9 (Polen): 2a B,

XX Hauptabteilung - Staatsarchiv Königsberg:

Herzogliches Briefarchiv: B1, Kasten 336

Etats Ministerium: $111 \mathrm{~m}$

\section{Źródła opublikowane}

Corpus iuris Polonici, t. 4/1, wyd. O. Balzer, Kraków 1910.

Divi Rudolphi II Imperatoris, Caesarii Augusti Epistolae Ineditae: Desumptae Ex Codice Manu Exarato Caesareo Classis Jur. Civ., wyd. B. Pace, Viennae 1771.

Heidenstein R., Dzieje Polski od śmierci Zygmunta Augusta do roku 1594, przeł. M. Gliszczyński, red. J. Byliński, W. Kaczorowski, Opole 2015.

Ottoman-Polish diplomatic relations (15th-18th century). An Annotated edition of Ahdnames and other documents, wyd. D. Kołodziejczyk, Leiden-Boston-Köln 2000.

Starożytności historyczne polskie, wyd. A. Grabowski, t. 2, Kraków 1840.

The House of Vasa and The House of Austria. Correspondence from the Years 1587 to 1668, cz. 1 (The Times of Sigismund III, 1587-1632. Volume 1), wyd. R. Skowron i inni, Katowice 2016.

Volumina Constitutionum, t. 2: 1550-1609, t. 2 (1587-1609), red. S. Grodziski, Warszawa 2008.

47 'Ahdname sułtana Murada III dla króla Zygmunta III, Stambuł, 10-18.10.1591, [w:] OttomanPolish Diplomatic relations (15th-18th century). An annotated edition of Ahdnames and other documents, wyd. D. Kołodziejczyk, Leiden-Boston-Köln 2000, nr 23, s. 284-288 i thumaczenie angielskie: s. 289293. 


\section{Opracowania}

Barwicka A., Rzeczpospolita w planach dyplomacji papieskiej i habsburskiej w okresie wojny austriackotureckiej 1593-1606, [w:] Polska wobec wielkich konfliktów w Europie nowożytnej, wyd. R. Skowron, Kraków 2009, s. 297-307.

Barwicka-Makula A., Od wrogości do przyjaźni. Habsburgowie austriaccy wobec Polski w latach 15871592, Katowice 2019.

Dybaś B., Powiat piltyński w XVII w. - jego geneza i status w Rzeczypospolitej, „Czasopismo Prawno-Historyczne" 2003, t. 55, nr 1, s. 201-215.

Filipczak-Kocur A., Skarbowość Rzeczypospolitej 1587-1648. Projekty-ustawy-realizacja, Warszawa 2006.

Gawron P., Jan Zamoyski, kanclerz i hetman wielki koronny, wobec zmagań turecko-habsburskich w latach 1593-1605/6, [w:] Polska wobec wielkich konfliktów w Europie nowożytnej, wyd. R. Skowron, Kraków 2009, s. 23-47.

Górski T., Flotylle kozackie w stużbie Jagiellonów i Wazów, Gdańsk 2006.

Gregorowicz D., Tiara w grze o korone. Stolica Apostolska wobec wolnych elekcji w Rzeczypospolitej Obojga Narodów w drugiej połowie XVI wieku, Kraków 2019.

Janiszewska-Mincer B., Mincer F., Rzeczpospolita Polska a Prusy Książęce w latach 1598-1621, Warszawa 1988.

Lepszy K., Rzeczpospolita Polska w dobie sejmu inkwizycyjnego (1589-1592), Oświęcim 2015 (reedycja).

Pieńkowski M. A., Kwestia wojny z Turcja na sejmie warszawskim 1590 roku, [w:] Studia historyczno-wojskowe, t. 6, red. K. Maksymiuk i inni, Siedlce 2015, s. 11-40.

Pieńkowski M. A., Trudna droga do władzy w Rzeczypospolitej. Sejm koronacyjny Zygmunta III 1587/1588 i sejm pacyfikacyjny 1589 roku, Warszawa 2021.

Plewczyński M., Wojny $i$ wojskowość polska w XVI wieku, t. 3 (1576-1599), Zabrze-Tarnowskie Góry 2013.

Poumarède G., L 'Empire de Venise et les Turcs XVIe-XVII' siècle, Paris 2020.

Sas J., Układy o Lige przeciw Turkom za Zygmunta III, „Przegląd Powszechny” 1899, t. 16, nr 63, s. 5471, 190-211 i nr 64, s. 350-369.

Tygielski W., Listy, ludzie, władza. Patronat Jana Zamoyskiego w świetle korespondencji, Warszawa 2008.

Wachowiak B., Kamieński A., Dzieje Brandenburgii-Prus na progu czasów nowożytnych (1500-1701), Poznań 2001.

Wimmer J., Wojsko i skarb Rzeczypospolitej u schyłku XVI $i$ w pierwszej połowie XVII wieku, „Studia i Materiały do Historii Wojskowości" 1968, t. 14, s. 3-91.

Wisner H., Dyplomacja polska w latach 1572-1648, [w:] Historia dyplomacji polskiej, red. G. Labuda, t. 2, Wrocław 1982, s. 5-161. 